\title{
OPTIMASI NAA DAN BAP TERHADAP PERTUMBUHAN DAN PERKEMBANGAN TUNAS MIKRO TANAMAN KANTONG SEMAR (Nepenthes mirabilis) SECARA IN VITRO
}

\author{
Optimize Of NAA And BAP On Growth And Development Of Micro Shoots Pitcher Plant \\ (Nepenthes Mirabilis)Through In Vitro \\ ROSMAINA DAN DINNI ARYANI \\ Fakultas Pertanian dan Peternakan UIN Sultan Syarif Kasim Riau \\ Jl. H.R. Soebrantas Km 16 Pekanbaru, Pekanbaru 28293 \\ Telp. +62-761-562051, Fax:+62-761-562052, \\ E-mail: rosmaina@uin-suska.ac.id
}

\begin{abstract}
Conventional propagation of Nepenthes was difficult to do. To overcome the problems were required alternative method such as in vitro propagation. The objective of this research was to obtain the best treatment of BAP + NAA on shoot multiplication of Nepenthes through in vitro culture. The research design used Randomized Completely Design consist of seven treatments, e.g. 1) $1 / 2$ MSO (control); 2) $1 / 2 M S+1 p p m B A P+0.5 p p m N A A ; 3) 1 / 2 M S+1 p p m B A P+1 p p m N A A ; 4) 1 / 2 M S+1.5 p p m B A P+$ 0.5 ppm NAA; 5) $1 / 2 \mathrm{MS}+1.5 \mathrm{ppm} B A P+1 \mathrm{ppm} \mathrm{NAA;6)} 1 / 2 \mathrm{MS}+2 \mathrm{ppm} B A P+0.5 \mathrm{ppm} N A A$ dan 7) $1 / 2 M S+2 p p m B A P+1 p p m N A A$. The parameter observed were number of shoot, number of nodul, number of leafs, number of pitcher and number of root. The result of this research showed that treatment of $1 / 2 M S+1 p p m B A P+1$ ppm NAA is the best treatment compared to others. At induction stage, this treatment can produce the number of shoot, number of nodul, and number of root were 1.6 shoots/explant, 10.8 nodul/explant and 3.6 root/explant, respectively. At subculture, this treatment can produce the number of shoot, number of leafs, and number of pitcher were 5.8 shoots/explant, 12.4 leafs/explant and 5.2 pitcher/explant, respectively.
\end{abstract}

Key words: Nepenthes mirabilis, NAA, BAP, micro shoot, in vitro

\section{PENDAHULUAN}

Kantong Semar (Nepenthes) merupakan salah satu tanaman karnivora yang unik dan menarik. Nepenthes termasuk salah satu sumber keanekaragaman hayati Indonesia yang terancam punah dan termasuk tanaman langka di dunia (CITES, 2012; Samsurianto, 2010; Handayani, 2006 dan Azwar et al., 2006). Nepenthes yang saat ini menjadi tanaman hias yang unik dan popular di Indonesia kebanyakan diperjual-belikan dan diambil langsung dari alam, bukan merupakan hasil penangkaran atau budidaya. Hal tersebut sangat memprihatinkan mengingat habitat asli Nepenthes yang terancam oleh kebakaran hutan, pembukaan lahan, pertambangan dan konversi lahan yang dapat menyebabkan hilangnya sumber plasma nutfah. Eksploitasi dari alam untuk kepentingan ekonomi yang tidak memperhatikan kaidah ekologi- konservasi akan mempercepat kepunahan Nepenthes di habitat alaminya (Giusto et al.,2008; Shingh et al.,2011; Mansur, 2008;Robinson et al., 2009). Kultur in vitro merupakan salah satu metode alternative yang dapat dilakukan untuk memperoleh tanaman Nepenthes dalam jumlah banyak dalam waktu singkat (Mansur, 2007;Rasco\&Maquilan, 2005;Dinarti et al, 2010; Yudhanto, 2012).

Kultur in vitro merupakan suatu metode mengisolasi bagian dari tanaman seperti protoplasma, sel, sekelompok sel, jaringan dan organ, serta menumbuhkannya dalam kondisi aseptik, sehingga bagian-bagian tersebut dapat memperbanyak diri dan beregenerasi menjadi tanaman yang lengkap. Perbanyakan Nepenthes melalui teknik kultur in vitro telah dilaporkan diantaranya oleh Isnaini (2009), Alitalia (2008), Sayekti (2007). Yudhanto (2012), Adrian (2011) dengan perlakuan terbaik adalah 0,5 ppm BAP pada 
media 1/3 MS yang menghasilkan 5,5 tunas/eksplan, Samsurianto (2010), Dinarti et al. (2010) menghasilkan 2,1 tunas/eksplan, Akan tetapi permasalahannya adalah jumlah tunas yang dihasilkan masih rendah yaitu berkisar 1,6-5,5 tunas/eksplan. Sehingga perlu dilakukan penelitian lanjutan untuk mencari konsentrasi media yang tepat untuk perbanyakan Nepenthes mirabilis. Penelitian ini bertujuan untuk mendapatkan konsentrasi NAA dan BAP yang optimal untuk pertumbuhan dan pekembangan tunas Nepenthes mirabilis.

\section{BAHAN DAN METODE}

Penelitian dilakukan di Laboratorium Genetika dan Pemuliaan Tanaman Fakultas Pertanian dan Peternakan Universitas Islam Negeri Sultan Syarif Kasim Riau. Bahan yang di gunakan adalah tunas mikro Nepenthes, media $1 / 2 \mathrm{MS}$, agar, gula, dan zat pengatur tumbuh (BAP dan NAA). Alat yang digunakan antara lain botol kultur, kotak tanam Rak penyimpanan kultur dilengkapi dengan penyinaran 1500 lux (16 jam)dan suhu ruang 18-22oC.

Penelitian ini disusun menggunakan Rancangan Acak Lengkap (RAL) dengan tujuh perlakuan pada tahap induksi yaitu : Perlakuan $11 / 2$ MS tanpa pemberian BAP dan NAA (kontrol),Perlakuan $2(1 / 2 \mathrm{MS}+\mathrm{BAP} 1 \mathrm{ppm}+$ NAA 0,5 ppm, Perlakuan $3(1 / 2$ MS + BAP 1 ppm + NAA 1 ppm), Perlakuan 4 (1/2 MS + BAP $1,5 \mathrm{ppm}+\mathrm{NAA} 0,5 \mathrm{ppm})$, Perlakuan 5 (1/2 MS + BAP 1,5 ppm + NAA 1 ppm), Perlakuan 6 (1/2 $\mathrm{MS}+\mathrm{BAP} 2 \mathrm{ppm}+\mathrm{NAA} 0,5 \mathrm{ppm})$, dan Perlakuan $7(1 / 2 \mathrm{MS}+\mathrm{BAP} 2 \mathrm{ppm}+\mathrm{NAA}$ $1 \mathrm{ppm})$. Masing-masing perlakuan terdiri dari 10 ulangan sehingga terdapat 70 satuan percobaan dengan 1 eksplan untuk setiap ulangannya. Setelah $10 \mathrm{MST}$, masing-masing perlakuan dari tahap induksi disubkultur pada media $1 / 2$ MSO selama 10 MST. Pengamatan dilakukan terhadap jumlah tunas, jumlah nodul, jumlah daun, jumlah kantong dan jumlah akar. Data yang diperoleh selanjutnya dilakukan ujiF. Parameter yang berbeda nyata pada uji $F$ dilakukan uji DMRT pada taraf $5 \%$.

\section{HASIL DAN PEMBAHASAN}

Secara umum, eksplan pada setiap perlakuan mulai menunjukkan respon pertumbuhan pada 1 Minggu Setelah Tanam (MST) ditandai dengan terjadinya pembengkakan pangkal atau bagian dasar eksplan dan pembentukan kalus atau nodul. Eksplan yang hidup dicirikan dengan warnanya masih hijau, tidak terkontaminasi oleh mikroorganisme, dan tidak kering. Zhang \& Lemaux (2005) menyatakan apabila eksplan mempunyai titik tumbuh dengan sel-sel meristematis yang ditanam dalam media regenerasi yang tepat, maka sel tersebut dapat langsung beregenerasi membentuk tunas.

Pembentukan tunas pada penelitian ini terjadi secara organogenesis langsung dan tidak langsung. Beberapa eksplan menghasilkan tunas secara langsung sedangkan sebagian besar lainnya membentuk nodul terlebih dahulu sebelum pecah menjadi tunas. Dhaliwal et al. (2004) menyatakan bahwa proses organogenesis eksplan secara in vitro terjadi dengan dua cara yang berbeda yaitu secara langsung dan tidak langsung. Hal yang sama juga pernah dilaporkan Rosmaina (2007) pada tanaman nenas, dimana organogenesis terjadi secara langsung dan tidak langsung. Kantong mulai terbentuk pada 3 MST pada ujung daun, sedangkan akar mulai terbentuk pada 5-6 MST.

Pada sebagian eksplan, nodul muncul pada bekas daun eksplan yang terpotong. Nodul awal yang terbentuk berwarna putih kehijauan, dan kemudian berubah warna menjadi coklat hingga kehitaman. Nodul mulai muncul pada minggu pertama dan semakin meningkat jumlahnya pada setiap minggu hingga 10 MST serta memiliki ukuran kecilkecil dan kompak. Pada 8-10 MST, sebagian besar dari nodul yang terbentuk ini mengalami pencoklatan yang parah, berwarna kuningcoklat hingga coklat kehitaman. Pencoklatan dalam kultur jaringan disebabkan karena meningkatnya produksi senyawa fenolat yang diikuti oksidasi oleh aktivitas enzim oksidase dan polimerasinya (Hutami, 2008).Pencoklatan yang semakin parah dapat mengakibatkan kematian eksplan untuk mengantisipasi hal tersebut, maka dilakukan subkultur pada media $1 / 2$ MSO, yaitu media tanpa pemberian 
zat pengatur tumbuh. Secara keseluruhan, pada penelitian ini diperoleh bahwa pemberian NAA + BAP mempengaruhi pertumbuhan danperkembangan eksplan Nepenthes pada beberapa parameter pengamatan. Pemberian BAP + NAA pada tahap induksi memberikan pengaruh sangat nyata terhadap jumlah nodul dan jumlah kantong serta memberikan pengaruh yang nyata terhadap jumlah daun dan jumlah akar namun tidak berpengaruh terhadap jumlah tunas.

Tabel 1. Rata-rata jumlah tunas, jumlah nodul, jumlah daun, jumlah kantong dan jumlah akar pada tahap induksi (TI) umur 10 MST dan Tahap Subkultur (SK)

\begin{tabular}{|c|c|c|c|c|c|c|c|c|c|c|}
\hline \multirow[t]{2}{*}{ Perlakuan } & \multicolumn{2}{|c|}{$\begin{array}{l}\text { Jumlah } \\
\text { Tunas }\end{array}$} & \multicolumn{2}{|c|}{$\begin{array}{l}\text { Jumlah } \\
\text { Nodul }\end{array}$} & \multicolumn{2}{|c|}{$\begin{array}{l}\text { Jumlah } \\
\text { Daun }\end{array}$} & \multicolumn{2}{|c|}{$\begin{array}{l}\text { Jumlah } \\
\text { Kantong }\end{array}$} & \multicolumn{2}{|c|}{ Jumlah Akar } \\
\hline & TI & SK & TI & SK & TI & SK & TI & SK & TI & SK \\
\hline $\begin{array}{l}\text { Kontrol } \\
1 \mathrm{ppm} \mathrm{BAP} \mathrm{+} \mathrm{0,5} \mathrm{ppm} \mathrm{NAA}\end{array}$ & $\begin{array}{l}0,0 \\
0,6\end{array}$ & $\begin{array}{l}0,0^{c} \\
1,8^{b}\end{array}$ & $\begin{array}{l}0,0^{d} \\
8,8^{b}\end{array}$ & $\begin{array}{l}0,0^{\mathrm{c}} \\
0,8^{\mathrm{bc}}\end{array}$ & $\begin{array}{l}8,0^{\mathbf{a}} \\
3,0^{\mathrm{b}}\end{array}$ & $\begin{array}{l}4,2^{\mathrm{b}} \\
9,2^{\mathrm{ab}}\end{array}$ & $\begin{array}{l}2,6^{\mathbf{a}} \\
0,0^{\mathrm{c}}\end{array}$ & $\begin{array}{l}0,6 \\
2,8\end{array}$ & $\begin{array}{l}0,0^{c} \\
0,0^{c}\end{array}$ & $\begin{array}{l}0,0 \\
1,6\end{array}$ \\
\hline 1 ppm BAP + 1 ppm NAA & 1,6 & $5,8^{a}$ & $10,8^{\mathrm{a}}$ & $0,8^{b c}$ & $3,4^{b}$ & $12,4^{a}$ & $0,4^{\mathrm{bc}}$ & 5,2 & $3,6^{\mathrm{a}}$ & 0,8 \\
\hline $\begin{array}{l}1,5 \mathrm{ppm} \text { BAP + 0,5 ppm NAA } \\
1,5 \mathrm{ppm} \mathrm{BAP} \mathrm{+} \mathrm{1} \mathrm{ppm} \mathrm{NAA} \\
2 \mathrm{ppm} \mathrm{BAP} \mathrm{+} \mathrm{0,5} \mathrm{ppm} \mathrm{NAA} \\
2 \text { ppm BAP + } 1 \text { ppm NAA }\end{array}$ & $\begin{array}{l}0,8 \\
0,6 \\
1,4 \\
1,0\end{array}$ & $\begin{array}{l}1,2^{b} \\
2,0^{b} \\
1,4^{b} \\
1,6^{b}\end{array}$ & $\begin{array}{l}7,2^{\mathrm{b}} \\
7,0^{\mathrm{b}} \\
4,6^{\mathrm{c}} \\
3,4^{\mathrm{c}}\end{array}$ & $\begin{array}{l}0,8^{\mathrm{bc}} \\
3,8^{\mathrm{ab}} \\
5,2^{\mathrm{a}} \\
6,2^{\mathrm{a}}\end{array}$ & $\begin{array}{l}2,8^{\mathrm{b}} \\
2,2^{\mathrm{b}} \\
7,2^{\mathrm{a}} \\
7,4^{\mathrm{a}}\end{array}$ & $\begin{array}{l}9,2^{\mathrm{ab}} \\
6,2^{\mathrm{b}} \\
4,4^{\mathrm{b}} \\
4,0^{\mathrm{b}}\end{array}$ & $\begin{array}{l}0,8^{\mathrm{b}} \\
0,8^{\mathrm{b}} \\
2,2^{\mathrm{a}} \\
2,4^{\mathrm{a}}\end{array}$ & $\begin{array}{l}1,2 \\
0,2 \\
0,0 \\
0,4\end{array}$ & $\begin{array}{l}0,6^{\mathrm{bc}} \\
1,6^{\mathrm{b}} \\
0,8^{\mathrm{bc}} \\
0,8^{\mathrm{bc}}\end{array}$ & $\begin{array}{l}0,2 \\
0,8 \\
0,0 \\
2,0\end{array}$ \\
\hline
\end{tabular}

Ket: Nilai yang diikuti oleh huruf yang sama pada kolom yang sama tidak berbeda nyata pada uji DMRT $5 \%$

Tabel 1 menunjukkan bahwa pada tahap induksi jumlah tunas tidak dipengaruhi oleh pemberian BAP + NAA pada setiap perlakuan, tetapi mempengaruhi jumlah daun, jumlah nodul, jumlah kantong dan jumlah akar, sedangkan pada tahap subkultur pemberian BAP + NAA memberikan pengaruh yang nyata terhadap jumlah tunas, jumlah nodul dan jumlah daun. Pada tahap induksi pemberian 1 ppm BAP + 1 ppm NAA menghasilkan ratarata jumlah tunas 1,6 tunas/eksplan dan tidak berbeda dengan perlakuan lainnya dan meningkat menjadi 5,8 tunas/eksplan pada tahap subkultur. Tanaman kontrol tidak membentuk tunas sama sekali, hanya mengalami pemanjangan tunas dan penambahan jumlah daun. Hasil ini lebih tinggi dari penelitian yang dilaporkan oleh Alitalia (2008) dan Dinarti et al. (2010) yang menghasilkan rata-rata 1,6 tunas/eksplan pada eksplan Nepenthes mirabilis dengan penambahan $1 \mathrm{ppm}$ BAP + 0,5 ppm NAA pada 16 MST dan 2,1 tunas/eksplan N. mirabilis selama 16 MST.

Hasil ini lebih baik dari yang dilaporkan oleh Sukamto et al. (2011) pada Nepenthes albomarginata bahwa pemberian BA $1 \mathrm{ppm}+$ NAA $1 \mathrm{ppm}$ pada media $1 / 2$ MS tidak menghasilkan tunas selama 12 MST. Samsurianto (2010) juga melaporkan persentase pembentukan tunas Nepenthes tertinggi yaitu $100 \%$ pada 5 MST dengan pemberian BAP $1 \mathrm{ppm}+0,1 \mathrm{TDZ}$ pada media $1 / 4 \mathrm{MS}$. Kombinasi $1 \mathrm{ppm}$ BAP dan $1 \mathrm{ppm}$ IAA juga dilaporkan memberikan jumlah tunas tertinggi pada tanaman krisan(Maryani \& Zamroni, 2005). Pemberian auksin dan sitokinin eksogen mampu memacu aktivitas auksin dan sitokinin endogen, sehingga mampu memacu pertumbuhan tunas.Basri (2008) menambahkan bahwa apabila terdapat keseimbangan yang sesuai antara ZPT yang ditambahkan ke media dan fitohormon yang dihasilkan dalam tanaman, akan diperoleh pertumbuhan daun ataupun tunas yang lebih baik.

\section{Jumlah Nodul}

Perlakuan 1 ppm BAP + 1 ppm NAA menghasilkan rata-rata jumlah nodul tertinggi yaitu 10,8 nodul/eksplan pada tahap induksi kemudian menurun menjadi pada 0.8 nodul/eksplan pada tahap subkultur, hal ini terjadi karena nodul pada tahap inisiasi telah pecah menjadi tunas pada tahap subkultur (Gambar 1).Perlakuan 2 ppm BAP + 1 ppm NAA dan perlakuan $2 \mathrm{ppm}$ BAP + 0,5 ppm NAA menghasilkan jumlah nodul tertinggi pada tahap subkultur yaitu 6.2 dan 5,2 nodul/eksplan (Tabel 1). Meningkatnya jumlah nodul pada pemberian 2 ppm BAP + 1 ppm NAA diduga karena adanya penurunan konsentrasi BAP dan NAA akibat subkultur pada media $1 / 2$ MSO. Sehingga kandungan 
sitokinin dan auksin pada eksplan berada dalam jumlah yang seimbang. Keseimbangan konsentrasi inilah yangdiduga menginduksi terbentuknya nodul. Sedangkan tanaman kontrol tetap tidak membentuk nodul sama seperti tahap perlakuan, sama halnya dengan hasil penelitian Sukamto et al. (2011) dan Samsurianto (2010), bahwa tidak ada nodul yang terbentuk pada tanaman kontrol

\section{Jumlah Daun dan Kantong}

Pada tahap induksi, tanaman kontrol menghasilkan rata-rata jumlah daun dan kantong tertinggi, yaitu 8 daun/eksplan dan 2,6 kantong/eksplan tidak berbeda nyata dengan perlakuan $2 \mathrm{ppm}$ BAP $+0,5 \mathrm{ppm}$ NAA yang mengasilkan rata-rata 7,2 daun/eksplan dan 2,2 kantong/eksplan dan perlakuan 2 ppm BAP + 1 ppm NAA yang menghasilkan rata-rata 7,4 daun/eksplan dan 2,4 kantong/eksplan. Kemudian menurun pada tahap subkultur, karena pada tahap subkultur perlakuan ini lebih banyak membentuk nodul, kecuali pada perlakuan kontrol. Pada tahap subkultur perlkuan yang menghasilkan jumlah tunas yang tinggi juga menghasilkan jumlah daun dan kantong yang tinggi yaitu perlakuan perlakuan $1 \mathrm{ppm}$ BAP $+1 \mathrm{ppm}$ NAA yang menghasilkan 12,4 daun/eksplan dan 5,2 kantong/eksplan (Gambar 1).

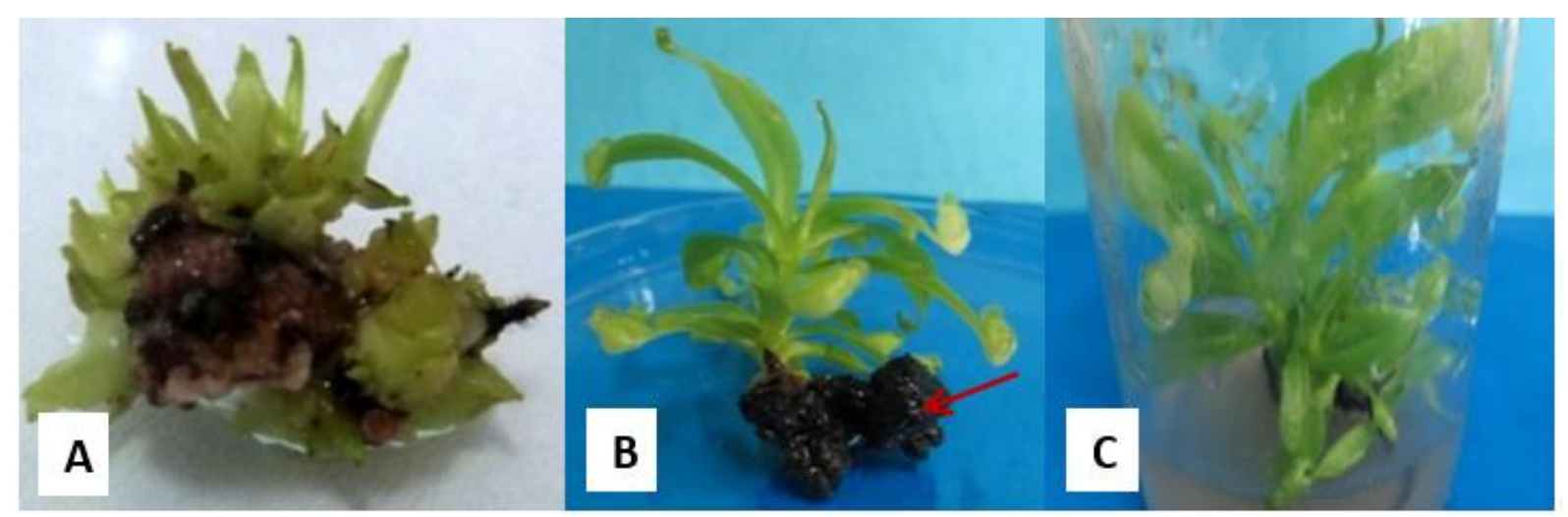

Gambar 1. Ekplan Nepenthes mirabilis pada inisiasi dan tahap subkultur $[A]$ tunas dan nodulyang terbentuk tahap inisiasipada perlakuan 1ppm BAP + 1 ppm NAA, [B] tunas yang dan nodul (nodul berwarna coklat kehitaman ditunjukkan oleh tanda panah) yang terbentuk pada tahap subkultur [C] planlet yang telah berumur $10 \mathrm{MST}$

\section{Jumlah Akar}

Rata-rata jumlah akar tertinggi pada tahap inisiasi dihasilkan perlakuan $1 \mathrm{ppm}$ BAP + 1 ppm NAA yaitu 3,6 akar/eksplan dan berbeda nyata dengan perlakuan lainnya. Tetapi pada tahap subkultur perlakuan2 ppm BAP + 1 ppm NAA menghasilkan rata-rata jumlah akar tertinggi yaitu 2.0 akar/eksplan. Pada tanaman control akar tidak terbentuk, begitu juga pada pemberian $1 \mathrm{ppm}$ BAP $+0,5$ ppm NAA

\section{Pembahasan}

Dari penelitian ini diperoleh dua metode perbanyakan tunas yaitu secara langsung dan tidak langsung (melalui nodul). Dalam perbanyakan langsung, eksplan yang meristematik akan langsung membentuk tunas, sedangkan pada diferensiasi tidak langsung, eksplan akan tumbuh menjadi kalus/nodul terlebih dahulu sebelum membentuk tunas (Wulandari, 2004; Santoso \& Nursandi, 2003; Rosmaina, 2010; Sukamto et al., 2011). Persentase hidup eksplan sangat tinggi, yaitu $97,14 \%$ pada tahap perlakuan dan subkultur. kemampuan hidup eksplan pada kultur in vitro sangat tergantung dari eksplan itu sendiri, jenis dan komposisi media serta kandungan zat pengatur tumbuh yang diberikan. Jenis dan komposisi media sangat mempengaruhi besarnya ketersediaan zat makanan bagi eksplan sehingga secara langsung dapat mempengaruhi besarnya daya tahan eksplan untuk hidup pada media tersebut, sedangkan zat pengatur tumbuh endogen dan eksogen berpengaruh terhadap besarnya penyerapan zat makanan yang tersedia.

Banyaknya tunas yang terbentuk pada tahap subkultur karena nodul yang terbentuk pada tahap inisiasi pecah menjadi tunas yaitu dari 10,8 nodul yang terbentuk pada tahap 
perlakuan, menghasilkan rata-rata 5,8 tunas/eksplan. Persentase nodul yang pecah membentuk tunas sekitar $50 \%$ pada $10 \mathrm{MST}$, sedangkan sisanya masih membentuk nodul.Pecahnya nodul menjadi tunas juga meningkatkan jumlah daun dan jumlah kantong. Hal ini diduga karena pemindahan eksplan pada media $1 / 2$ MSO menurunkan kandungan sitokinin dan auksin dari media sebelumnya, sehingga penurunan konsentrasi auksin dan sitokinin pada eksplan dapat menginduksi pecahnya nodul menjadi tunas, sementara sisa nodul yang $50 \%$ yang tidak pecah menjadi tunas mengalami pembengkakan/pembesaran nodul dan mulai terlihat adanya titik tumbuh, sehingga diduga nodul ini dapat pecah menjadi tunas apabila disubkultur kembali pada media baru. Secara umum terlihat bahwa subkultur pada media 1/2 MSO meningkatkan jumlah tunas.Setelah melalui fase induksi dalam media yang mengandung ZPT, sel memasuki fase diferensiasi kedua dalam medium MSO yaitu perkembangan morfologis atau pembentukan organ (Mattjik, 2005).Hal yang sama juga pernah dilaporkan oleh Rosmaina, (2010) pada tanaman nenas; Samsurianto, (2010) pada tanaman kantung semar, Rainiyati, (2009) pada tanaman pisang dan Kristina, (2009) pada Ficus deltoidea Jack.

Peningkatan konsentrasi 2 ppm BAP + 1 ppm NAA menurunkan jumlah tunas yang terbentuk pada tahap induksi, tetapi menghasilkan jumlah nodul yang tinggi pada tahap subkultur, diduga terjadi penurunan konsentrasi auksin dan sitokinin secara endogen dan hal ini menyebabkabkan keseimbangan baru didalam sel, sehingga menginduksi pembelahan sel yang terlihat dari pembentukan nodul.Kasus serupa juga dilaporkan terjadi pada tanaman Persea Americana (Zulfiqar et al., 2009) dan pada tanaman krisan(Lisan, 2005).Pemberian ZPT dengan konsentrasi tinggi menyebabkan aktivitas pembelahan sel menjadi lambat, sehingga kecil pengaruhnya terhadap peningkatan pertumbuhan tanaman.Dinarti et al. (2010) melaporkan bahwa kandungan sitokinin endogen yang cukup tinggi pada eksplan Nepenthes mirabilis menyebabkan eksplan tidak rensponsif terhadap pembentukan tunas.Akibatnya penambahan sitokinin eksogen tidak lagi berpengaruh bahkan dapat menghambat pertumbuhan tunas karena konsentrasi sitokinin menjadi eksesif (supra optimal).

Setelah mencapai kadar optimal, peningkatan konsentrasi sitokinin dan auksin menghambat pertumbuhan tanaman (Imelda et al., 2008; Ali et al., 2008; Sukmadjaja \& Mulyana, 2011). Berbeda dengan tanaman kontrol, eksplan tidak mampu membentuk tunas baik pada tahap induksi maupun tahap subkultur, karena hormon auksin dan sitokinin endogen yang terdapat pada eksplan semakin menurun jumlahnya ketika disubkultur pada media $1 / 2$ MS0, sehingga eksplan tidak mampu membentuk tunas. Bustami (2011) melaporkan pada tanaman kacang tanah tanpa penambahan zat pengatur tumbuhdalam media pertumbuhan menjadi terhambat, bahkan dapat menyebabkan eksplan tidak tumbuh.

Daun yang terbentuk pada tahap inisisasi paling tinggi diperoleh pada tanaman kontrol, tetapi pada tahap subkultur jumlah daun dan kantong terbanyak diperoleh dari perlakuan 1 ppm BAP + 1 ppm NAA, hal ini karena pada tahap subkultur perlakuan ini menghasilkan banyak tunas dari pecahnya nodul sehingga meningkatkan jumlah daun dan jumlah kantong. Tingginya jumlah daun pada tanaman kontrol pada tahap induksi juga dilaporkan oleh Alitalia (2008) yang juga menghasilkan jumlah daun tertinggi, yaitu 4,1 daun/eksplan.

Pada penelitian ini, baik pada tahap perlakuan maupun pada tahap subkultur, jumlah akar yang terbentuk pada tanaman Nepenthes relatif sedikit sesuai dengan kondisi Nepenthes di lapang. Penelitian Devi (2012) melaporkan bahwa kesulitan dalam perbanyakan Nepenthes adalah pertumbuhan tunas, daun dan kantong lebih dulu muncul dibanding akar, sehingga pada 3 minggu setelah munculnya daun, tingkat kematian stek sangat tinggi karena tanaman tidak mendapatkan suplai unsur hara dari akar karena akar belum terbentuk. Sulitnya akar tumbuh dapat dipengaruhi oleh faktor internal dan eksternal.Faktor internal yaitu faktor genetik, ketersediaan air dalam jaringan, kandungan cadangan makanan, umur tanaman dan hormon endogen. Sedangkan faktor eksternal antara lain adalah media perakaran, kelembapan, suhu dan cahaya 
(Pemungkas et al., 2009). Jumlah akar yang berjumlah sedikit ini menunjukkan bahwa fungsi akar tidak terlalu berperan dalam memberikan stok hara bagi pertumbuhan tanaman karena tanaman ini biasa tumbuh pada daerah yang miskin unsur hara (Sayekti, 2007; Samsurianto, 2010; Alitalia, 2008).

\section{KESIMPULAN DAN SARAN}

\section{Kesimpulan}

Berdasarkan hasil penelitian menunjukkan bahwa konsentrasi 1 ppm BAP + 1 ppm NAA pada media $1 / 2$ MS merupakan perlakuan terbaik untuk pertumbuhan dan perkembangan tunas mikro Nepenthes mirabilis, dimana jumlah tunas yang dihasilkan berkisar antara 2-12 tunas/eksplan dengan rata-rata 5,8 tunas/eksplan selama 10 MST.

\section{DAFTAR PUSTAKA}

Adrian. 2011. Pengaruh Pemberian Hormon BAP terhadap Multiplikasi Tunas Tumbuhan kantong Semar (Nepenthes alata Blanco) pada Media Tanam Murashige \& Skoog dengan Teknik In vitro. Skripsi. Departemen Konserbasi Sumber Daya Hutan dan Ekowisata. Fakultas Kehutanan. Institut Pertanian Bogor. 63 hal

Ali, G., Hadi, Z. Ali, M. Tariq and M. Khan. 2008. Callus induction and in vitro complete plant regeneration of different cultivars ot tobacco (Nicotiana tabacum L.) on media of different hormonal concentration. Biotechnology, 6(4): 561566

Alitalia, Y. 2008. Pengaruh pemberian BAP dan NAA terhadap pertumbuhan dan perkembangan tunas mikro kantong semar (Nepenthes mirabilis). Skripsi. Program Studi Hortikultura, Fakultas Pertanian Institut Pertanian Bogor. 80 hal.

Azwar, F., Adi dan Teten.2006. Kantong Semar (Nephentes sp.) di Hutan Sumatera, Tanaman Unik yang Semakin Langka. Makalah Penunjang pada Ekspose Hasil-hasil Penelitian: Konservasi dan Rehabilitasi Sumberdaya Hutan. Padang, 20 September 2006.
Basri, Z. 2008. Multiplikasi empat varietas krisan melalui teknik kultur jaringan. Jurnal Agroland, 15(4) : 271-22

Bustami, M. U. 2011. Penggunaan 2,4-D untuk induksi kalus kacang tanah. Media Litbang Sulteng, 4(2): 137 - 141

CITES. 2012. Convention On International Trade In Endangered Species Of Wild Fauna And Flora. Seventeenth Meeting Of The Plants Committee Geneva (Switzerland).

Devi, S. 2012. Perbanyakan vegetative tanaman kantong semar (Nepenthes sp) melalui stek batang dengan berbagai taraf konsentrasi NAA. Skripsi. Jurusan agroteknologi Fakultas Pertanian dan Peternakan Universitas Islam Negeri Sultan Syarif Kasim Riau. 87 hal

Dhaliwal, H. S., E. C. Yeung and T. A. Thorpe. 2004. Tiba inhibition of in vitro organogenesis in excised tobacco leaf explants. In vitro cell Development of Biology Plant, 40: 235-238

Dinarti, D. USay ekti dan A. Alitalia. 2010. Kultur jaringan kantong semar (Nepenthes mirabilis). Jurnal Holtikultura Indonesia, 1(2): 59-65

Giusto, D., Bruno, V. Grosbois, E. Fargeas, D. J. Marshall and L. Gaume. 2008. Contribution of pitcher fragrance and fluid viscosity to high prey diversity in a Nepenthes carnivorous plant from Borneo. Journal of Biology Science, 33(1): 121-136

Handayani, T. 2006. Perbanyakan Tanaman Kantong semar (Nepenthes spp.).www.lipi.go.id. Diakses 30 Februari 2012.

Hutami, S. 2008. Masalah Pencoklatan pada Kultur jaringan. Jurnal Agrobiogen, 4(2): 83-88

Imelda, M., W. Aida dan P.Y. Suryasari. 2008. Regenerasi tunas dari kultur tangkai daun iles-iles (Amorphophallus muelleri Blume). Biodiversitas, 9(3): 173-176

Isnaini, Y. 2009. Perkecambahan Biji Kantong Semar (Nepenthes ampullaria Jack.) Pada Berbagai Media In Vitro dan Di Rumah Kaca. Pusat Konservasi Tumbuhan Kebun Raya Bogor.LIPI. Bogor. 
Kristina, N. N. 2009. Induksi Tunas tabat Barito (Ficus deltoidea Jack) secara in vitro menggunakan Benzil Adenin (BA) dan Naphthalene Acetic Acid (NAA). Jurnal Littri, 15(1): 33-39

Lisan, E. 2005.Morfogenesis langsung pada tanaman krisan (Chrysanthemum $s p$ ). Jurnal Agrivigor, 5(1) : 64-72

Mansur, M. 2007. Nepenthes Kantong Semar yang Unik. Penebar Swadaya. Jakarta. 100 hal.

Maryani, Y dan Zamroni.2005.Penggandaan Tunas Krisan Melalui Kultur Jaringan. Jurnal IImu Pertanian, 12(1): 51-55

Mattjik, N.A. 2005. Peran Kultur Jaringan Dalam Perbaikan Tanaman. Orasi Ilmiah Guru Besar Tetap Kultur Jaringan Fakultas Pertanian Institut Pertanian Bogor.101 hal.

Rasco, J.R dan M. Maquilan. 2005. Initial studies on in vitro germination and early seedling growth of Nepenthes truncate Macf. Carnivorous Plant Newsletter, 34: 51-53

Rainiyati, Lizawati dan Mitra. 2009. Peranan IAA dan BAP terhadap Perkembangan Nodul pisang (Musa AAb) Raja Nangka secara in vitro. Jurnal Agronomi, 13(1): 51-57

Robinson, A.S., Andreas, Stewart, Heinrich, Gironella and Pena. 2009. A Spectacular new spesies of Nepenthes $\mathrm{L}$ (Nepentheceae) pitcher plant from central Palawan, Philippines. Journal of the Linnean Society, 159: 195-202

Rosmaina, 2010.Laju multiplikasi nenas (Ananas cmosus L) pada media dasar MS hasil perlakuan BA dan NAA secara in vitro.Jurnal Agroteknologi. 1(1): 32-37

Rosmaina. 2007. Optimasi BA/TDZ dan NAA untuk perbanyakan massal nenas(Ananas cmosus L) kultivar smooth cayene melalui teknik in vitro.
Tesis. Sekolah Pasca Sarjana Institut Pertanian Bogor.76 hal.

Samsurianto. 2010. Induksi tunas mikro kantong semar (Nepenthes spp.) in vitro. Bioprospek, 7(2): 67-76

Sayekti, U. 2007. Pengaruh Media Terhadap Pertumbuhan dan Perkembangan Kecambah Kantong Semar (Nepenthes mirabilis) secara In Vitro. Skripsi. Fakultas Pertanian, Institut Pertanian Bogor. Bogor. 62 hal.

Singh, B., Phukan, Sinha, V.N Singh and S.K. Borthakur. 2011. Conservation strategies for Nepenthes Khasiana in the Nokrek biosphere reserve of Garo hills, Northeast, India. International Journal of Conversation Science, 2(1): 55-64

Sukamto, L. A., Mujiono, Djukri dan Victoria. 2011. Shoot Tip culture of Nepenthes albomarginata. Jurnal Biologi Indonesia, 7(2): 251-261

Sukmadjaja, D dan A. Mulyana. 2011. Regenerasi dan Pertumbuhan Beberapa Varietas Tebu (Saccharum officinale) Secara in vitro. Jurnal Agrobiogen, 7(2): 106-118

Yudhanto, A. S. 2012. Pengaruh kombinasi NAA dan Sitokinin (BAP, Kinetin, dan 2ip) terhadap daya Proliferasi Tanaman Kantong Semar (Nepenthes mirabilis) secara In vitro. Skripsi. Departemen Agronomi dan Hortikultura. Fakultas Pertanian Institut Pertanian Bogor.45 hal.

Zang and P.G. Lemaux. 2005. Molecular aspect of in vitro shoot organogenesis. In R.N. Trigiano and D.J Gray: 173-185

Zulfiqar, Bushra, Akhtar, A.Touqeer and I. A. Hafiz. 2009. Effect of explant sources and different concentrations of plant growth regulators on in vitro shoot proliferation and rooting of avocado (Persea Americana Mill.). Journal of Botany, 41(5): 2333-2346 
Optimasi NAA dan BAP (Rosmaina dan Dinni Aryani) 


\section{J U R N A L AGROTEKNOLOGI Journal of Agrotechnology}

PENGARUH PEMBERIAN PUPUK KALIUM DAN CAMPURAN KOMPOS TANDAN KOSONG KELAPA SAWIT DENGAN ABU BOILER TERHADAP PERTUMBUHAN DAN HASIL TANAMAN BAWANG MERAH (Allium asacalonicum L.)

The Effect of Potassium Fertilizer and Compost Mixture of Oil Palm Empty Bunches with Boiler Ash on Growth and Yield of Onion (Allium ascalonicum L.)

Dian Fikri Alfian, Nelvia, Husna Yetti

DAMPAK PERKEBUNAN KELAPA SAWIT TERHADAP PEREKONOMIAN WILAYAH DI KABUPATEN ROKAN HULU

The Impact of Palm Plantation Development in the Economic Region in Rokan Hulu district Irsyadi Siradjuddin

OPTIMASI METODE ISOLASI DNA PADA Jatropha spp.

Optimation of DNA Isolation Method on Jatropha spp.

Kristianto Nugroho, Rerenstradika T. Terryana, dan Puji Lestari

ANALISIS SIFAT FISIKA TANAH GAMBUT PADA HUTAN GAMBUT DI KECAMATAN TAMBANG KABUPATEN KAMPAR PROVINSI RIAU

Analysis of Soil Physical Peat Land in Peat Forests in Tambang Sub-District, Kampar District, Riau Province

Susandi, Oksana, dan Ahmad Taufiq Arminudin

OPTIMASI NAA DAN BAP TERHADAP PERTUMBUHAN DAN PERKEMBANGAN TUNAS MIKRO TANAMAN KANTONG SEMAR (Nepenthes mirabilis) SECARA IN VITRO

Optimize Of NAA And BAP On Growth And Development Of Micro Shoots Pitcher Plant (Nepenthes Mirabilis)Through In Vitro

Rosmaina dan Dinni Aryani

APLIKASI PUPUK KANDANG SAPI DAN AYAM TERHADAP PERTUMBUHAN DAN HASIL TANAMAN JAHE (Zingiber officinale Rosc.) DI MEDIA GAMBUT

The Application of Cattle Chicken Manures With Different Dosages on The Growth and Yield of Ginger (Zingiber officinale Rosc.) in Peat Media

Yuliana, Elfi Rahmadani, dan Indah Permanasari 